Research Article

\title{
Preparation, Characterization and NO-CO Redox Reaction Studies over Palladium and Rhodium Oxides Supported on Manganese Dioxide
}

\author{
M.S. Fal Desai, R.K. Kunkalekar, A.V. Salker* \\ Department of Chemistry, Goa University, Goa 403206, India
}

Received: 22nd November 2014; Revised: 31st January 2015; Accepted: 2nd January 2015

\section{Abstract}

The catalytic activity of $\mathrm{PdO} / \mathrm{MnO}_{2}$ and $\mathrm{Rh}_{2} \mathrm{O}_{3} / \mathrm{MnO}_{2}$ is investigated for NO-CO redox reaction. Supported catalysts are prepared by wet impregnation method. Among the tested catalysts, $\mathrm{PdO} / \mathrm{MnO}_{2}$ shows higher activity for this reaction. Active metal dispersion on $\mathrm{MnO}_{2}$ enhances the selectivity for $\mathrm{N}_{2}$ over $\mathrm{N}_{2} \mathrm{O}$ in this reaction. The XRD substantiate the formation of $\mathrm{MnO}_{2}$ monophasic phase. SEM images show the formation of elongated particles. TEM images indicate nano-size rod-like morphologies. An increase in the catalytic activity is observed on supported $\mathrm{Pd}$ and $\mathrm{Rh}$ oxides on $\mathrm{MnO}_{2}$. Temperature programmed desorption studies with NO and CO are undertaken to investigate the catalytic surface studies. (C) 2015 BCREC UNDIP. All rights reserved

Keywords: Nitric oxide; Carbon monoxide; $\mathrm{MnO}_{2} ; \mathrm{PdO} ; \mathrm{Rh}_{2} \mathrm{O}_{3}$

How to Cite: Fal Desai, M.S., Kunkalekar, R.K., Salker, A.V. (2015). Preparation, Characterization and NO-CO Redox Reaction Studies over Palladium and Rhodium Oxides Supported on Manganese Dioxide. Bulletin of Chemical Reaction Engineering \& Catalysis, 10 (1): 98-103.

(doi:10.9767/bcrec.10.1.7802.98-103)

Permalink/DOI: http://dx.doi.org/10.9767/bcrec.10.1.7802.98-103

\section{Introduction}

Oxides of nitrogen $\left(\mathrm{NO}_{\mathrm{x}}\right)$ and carbon monoxide $(\mathrm{CO})$ are unambiguously serious air pollutants and harmful to living beings. $\mathrm{NO}_{\mathrm{x}}$ is a major cause of acid rain and photochemical smog. Both NO and CO are mostly produced as exhaust gases from motor vehicles and industries. Several methods have been developed for the $\mathrm{NO}$ and CO removal to meet the increasingly stringent regulations imposed on exhaust emissions. Fortunately, catalytic method for the redox reaction is available and is considered to be a powerful technique in detoxification of these gases. The efforts of the researchers are directed towards the development of various new

* Corresponding author.

E-mail: sav@unigoa.ac.in, avsalker@yahoo.com

(Salker, AV.)

Tel.: +91-832-6519315, Fax: +91-832-2452889 catalytic methods to control the emission of these pollutants in the environment [1-4]. Selective catalytic reduction (SCR) of $\mathrm{NO}_{\mathrm{x}}$ is one of the most efficient and economical technology for the removal of $\mathrm{NO}_{\mathrm{x}}$ by using reducing agents such as $\mathrm{NH}_{3}$, hydrocarbons, $\mathrm{CO}$ and $\mathrm{H}_{2}$ [1-8]. CO as a reducing gas offers some distinct advantages of being emitted from the same exhaust of vehicles due to the incomplete combustion of fossil fuels. Lot of research has been focussed on developing catalysts for the reduction of NO by $\mathrm{CO}$ which will promote the simultaneous detoxification of these two pollutants [712]. Most of the reported catalysts tested for NO-CO reaction give complete NO conversion at much higher temperatures and hence it is necessary to develop a catalyst which can give complete NO-CO conversion to nitrogen and $\mathrm{CO}_{2}$ at comparatively lower temperatures.

$\mathrm{MnO}_{2}$ with different crystallographic forms and morphologies is one of the most striking 
materials because of its valuable technological applications in catalysis, electrochemistry, molecular adsorption, waste removal, ion exchange processes and magnetic applications [7, $8,12-15]$. It has superior ability to activate and supply oxygen which is helpful in catalytic redox reactions. Nano-sized $\mathrm{MnO}_{2}$ is expected to exhibit good performance because of its large surface area and good activity. The properties of $\mathrm{MnO}_{2}$ are influenced significantly by its structure, morphology and preparative methods. Different types of manganese oxides, doped manganese oxides, mixed manganese oxides, metal supported manganese oxides are widely used for $\mathrm{NO}$ reduction and $\mathrm{CO}$ oxidation reactions [3-8, 13-16]. $\mathrm{MnO}_{2}$ exhibits considerable enhance activity when incorporated with some active metals or metal oxides. There are scanty reports of precious metals or metal oxides supported on $\mathrm{MnO}_{2}$ catalysts for lower temperature NO-CO reaction.

The present investigation reports the preparation of palladium and rhodium oxides supported on manganese dioxide by wet impregnation method. The catalysts are characterized by different instrumental techniques and tested for NO - CO redox reactions. Active metal substitution enhances the activity and selectivity for $\mathrm{N}_{2}$ in NO-CO reaction. Chemisorption of $\mathrm{CO}$ and NO was studied over these catalysts.

\section{Experimental}

\subsection{Catalysts Preparation}

$\mathrm{PdO} / \mathrm{MnO}_{2}$ with 5.9 wt\% Pd loading and $\mathrm{Rh}_{2} \mathrm{O}_{3} / \mathrm{MnO}_{2}$ with 5.7 wt\% Rh loading catalysts were prepared by wet impregnation method. The nano-sized pristine $\mathrm{MnO}_{2}$ powder was prepared by dextrose assisted co-precipitation method. $\mathrm{Mn}\left(\mathrm{CH}_{3} \mathrm{COO}\right)_{2} .4 \mathrm{H}_{2} \mathrm{O}$ (Sigma-aldrich $99.9 \%$ ) was dissolved in distilled water and $2 \%$ of dextrose solution was added at $100{ }^{\circ} \mathrm{C}$. Precipitation was carried out by dropwise addition of $10 \% \mathrm{NaOH}$ solution under vigorous stirring. This suspension of manganese hydroxide $(\mathrm{pH}=9)$ was subjected to oxidation using $30 \%$ $\mathrm{H}_{2} \mathrm{O}_{2}$. The precipitate was then filtered, washed and dried at $120^{\circ} \mathrm{C}$ for $10 \mathrm{~h} . \mathrm{MnO}_{2}$ was mixed with an aqueous solution of appropriate amount of metal ions $\left(\mathrm{PdCl}_{2}\right.$ and $\mathrm{RhCl}_{3}$ from Sigma Aldrich, 99.9 and $99.98 \%$ respectively) under vigorous stirring. Sodium hydroxide $(10 \%)$ solution was added drop wise with the constant stirring to precipitate supported metals as metal hydroxide. Solution was allowed to stand and then checked for the complete precipitation by adding more $\mathrm{NaOH}$. The precipitate was filtered, washed with distilled water and dried in air. The obtained samples were homogenized well in mortar and pestle and dried at $250{ }^{\circ} \mathrm{C}$ for $5 \mathrm{~h}$.

\subsection{Catalysts Characterization}

X-ray powder diffraction measurement was carried out on a RIGAKU diffractometer, using $\mathrm{Cu} K a$ radiation $(\lambda=1.5418 \AA$, filtered through $\mathrm{Ni}$ filter) to investigate the structure as well as phase of the prepared catalysts. The surface morphology was determined with JSM-5800LV Scanning Electron Microscope (SEM). The Transmission electron microscope (TEM) images were recorded using PHILIPS CM 200 electron microscope with a resolution of $2.4 \AA$. The BET surface area was measured by nitrogen adsorption at liquid Nitrogen temperature using SMART SORB-91 surface area analyzer. NO and CO TPD studies of the samples were carried out using Quantachrome Autosorb iQ. For TPD studies $5 \%$ of gas (CO or NO) in $\mathrm{N}_{2}$ was passed over $0.2 \mathrm{~g}$ of catalyst at $100{ }^{\circ} \mathrm{C}$ for 30 mins, then cooled and flushed with $\mathrm{N}_{2}$ and sample was subjected to TPD analysis using TCD detector. FTIR spectra of NO adsorbed samples were recorded at room temperature using Shimadzu IR Prestige 21 spectrometer.

\subsection{Catalytic Activity Tests}

The catalytic tests for $\mathrm{NO}$ reduction by $\mathrm{CO}$ were performed in a continuous flow, fixed bed glass reactor. The catalyst powder weighing 0.9 $\mathrm{g}$ was supported between glass wool plugs in a glass reactor which was placed in an electric furnace. Catalytic activity was determined using a feed gas composition of 5\% NO and 5\% CO in $90 \%$ argon and passed over the catalyst at a rate of $5000 \mathrm{ml} \mathrm{h}^{-1}$. The catalysts were heated in $\mathrm{N}_{2}$ atmosphere at $100{ }^{\circ} \mathrm{C}$ for $20 \mathrm{~min}$ prior to the reaction. The feed gases and the products were analyzed employing an online Gas Chromatograph with molecular sieve 13X and Porapak Q columns with $\mathrm{H}_{2}$ as a carrier gas.

\section{Results and Discussion}

\subsection{Catalysts Characterization}

Figure 1a shows the XRD pattern of pristine $\mathrm{MnO}_{2}$. The $\mathrm{MnO}_{2}$ shows diffraction features characteristic of tetragonal $\mathrm{MnO}_{2}$ phase, which is in agreement with the reported literature data (ICDD card 44-0141). $\mathrm{PdO} / \mathrm{MnO}_{2}$ and $\mathrm{Rh}_{2} \mathrm{O}_{3} / \mathrm{MnO}_{2}$ catalysts show diffraction pattern similar to pristine $\mathrm{MnO}_{2}$ (Figures $1 \mathrm{~b}$ and 1c). Both $\mathrm{Pd}$ and $\mathrm{Rh}$ oxides are present over $\mathrm{MnO}_{2}$ support. Low intensity peaks with broader 
widths are observed, indicating the poor crystallinity and nano size of these catalysts. Since $\mathrm{Pd}$ and $\mathrm{Rh}$ oxides are highly dispersed over $\mathrm{MnO}_{2}$ support in low concentration, no extra reflections are observed in the XRD pattern.

The topography and morphological features of the samples are investigated by SEM. Figure 2 shows the SEM images of (a) $\mathrm{PdO} / \mathrm{MnO}_{2}$ and (b) $\mathrm{Rh}_{2} \mathrm{O}_{3} / \mathrm{MnO}_{2}$ catalysts. The SEM images show the aggregates of fine particles. The aggregates have moderately elongated rod-like morphology. The representative TEM images are given for pristine $\mathrm{MnO}_{2}$ and $\mathrm{Rh}_{2} \mathrm{O}_{3} / \mathrm{MnO}_{2}$ catalysts (Figures 2c and 2d). From Figure 2c, it can be seen that $\mathrm{MnO}_{2}$ catalyst shows rod-

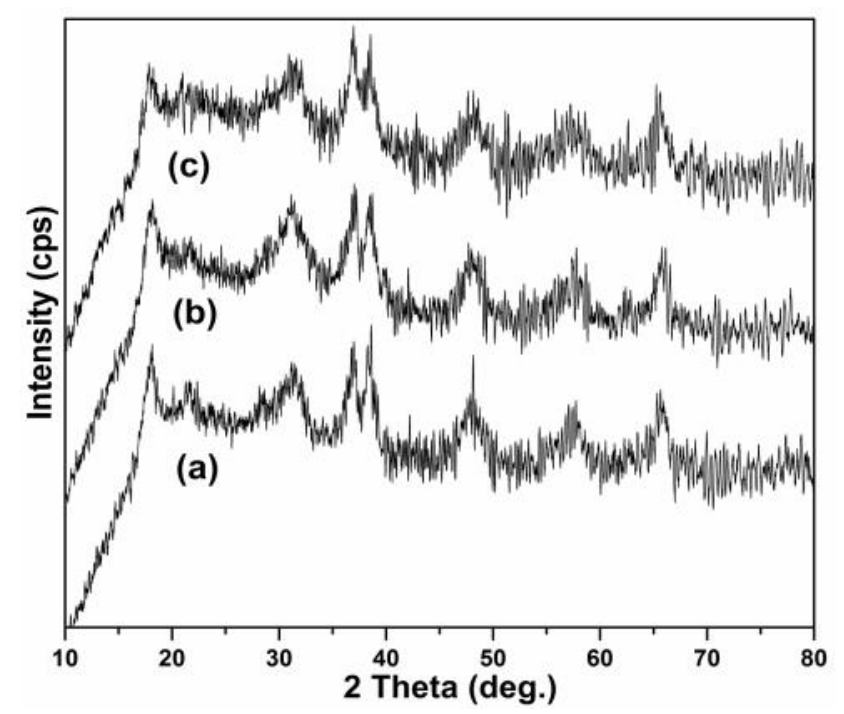

Figure 1. XRD patterns of (a) $\mathrm{MnO}_{2}$, (b) $\mathrm{PdO} / \mathrm{MnO}_{2}$ and (c) $\mathrm{Rh}_{2} \mathrm{O}_{3} / \mathrm{MnO}_{2}$
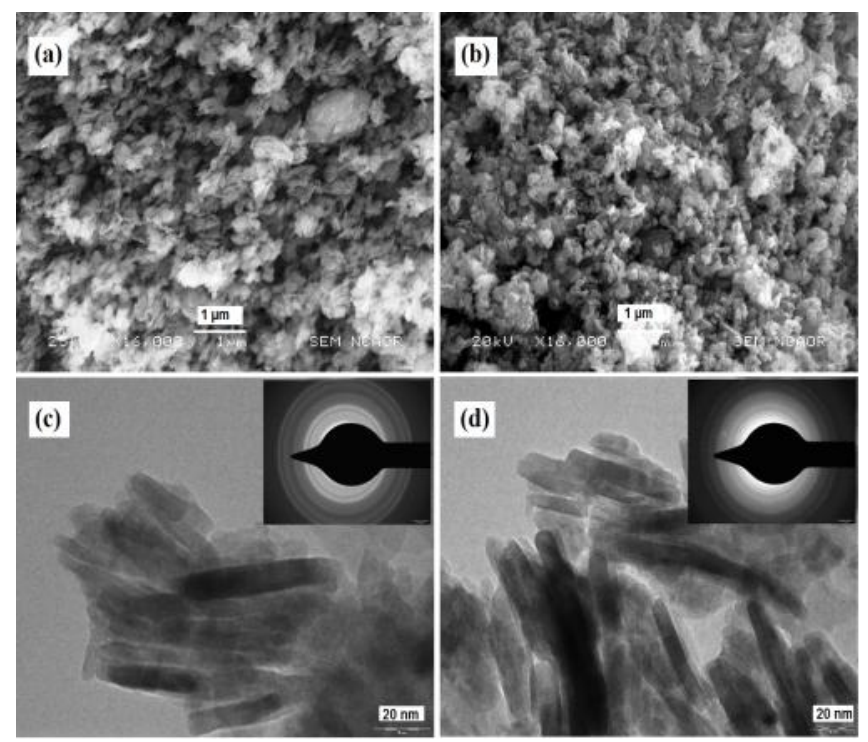

Figure 2. SEM images of (a) $\mathrm{PdO} / \mathrm{MnO}_{2}$, (b) $\mathrm{Rh}_{2} \mathrm{O}_{3} / \mathrm{MnO}_{2}$ and TEM images of (c) $\mathrm{MnO}_{2}$, (d) $\mathrm{Rh}_{2} \mathrm{O}_{3} / \mathrm{MnO}_{2}$ like nano particles with thickness less than 10 $\mathrm{nm}$. Similar features are shown by $\mathrm{Rh}_{2} \mathrm{O}_{3} / \mathrm{MnO}_{2}$ catalyst (Figure 2d). Inset in both the TEM images illustrate electron diffraction patterns. The electron diffraction patterns show clear concentric ring patterns indicating polycrystalline nature of the samples. These results are further supported by noisy X-ray diffraction pattern indicating nano-crystalline nature of these samples.

The BET surface area of all the catalysts is determined using nitrogen adsorption at boiling liquid nitrogen temperature. The BET surface areas of $\mathrm{MnO}_{2}, \quad \mathrm{PdO} / \mathrm{MnO}_{2}$ and $\mathrm{Rh}_{2} \mathrm{O}_{3} / \mathrm{MnO}_{2}$ are found to be 62,65 and $60 \mathrm{~m}^{2} \mathrm{~g}^{-1}$ respectively. Current preparation procedure was successful in getting uniform and high surface area catalysts.

\subsection{NO Reduction by CO}

Catalytic NO reduction by CO over different catalysts as a function of temperature is presented in Figure 3. The results show that the products of $\mathrm{NO}$ reduction by $\mathrm{CO}$ for all samples are $\mathrm{N}_{2}$ and $\mathrm{CO}_{2} . \mathrm{N}_{2} \mathrm{O}$ formation is observed at lower temperature (Figure 4). From the figure it is clear that the supported catalysts show much higher activity than pristine $\mathrm{MnO}_{2}$. $\mathrm{PdO} / \mathrm{MnO}_{2}$ shows higher activity than $\mathrm{Rh}_{2} \mathrm{O}_{3} / \mathrm{MnO}_{2}$ catalyst. Catalysts such as $\mathrm{Pd} / \mathrm{Al}_{2} \mathrm{O}_{3}, \mathrm{Rh} / \mathrm{Al}_{2} \mathrm{O}_{3}$ and $\mathrm{Rh} / \mathrm{AlPO}_{4}$ reported in literature exhibit lower activity for NO reduction by $\mathrm{CO}$, exhibiting conversion at higher temperatures [17-18]. The light-off temperature ( $\mathrm{T}_{50}$ i.e. $50 \%$ conversion) of $\mathrm{MnO}_{2}$ is observed at $318{ }^{\circ} \mathrm{C} . \mathrm{PdO} / \mathrm{MnO}_{2}$ shows $\mathrm{T}_{50}$ at 160

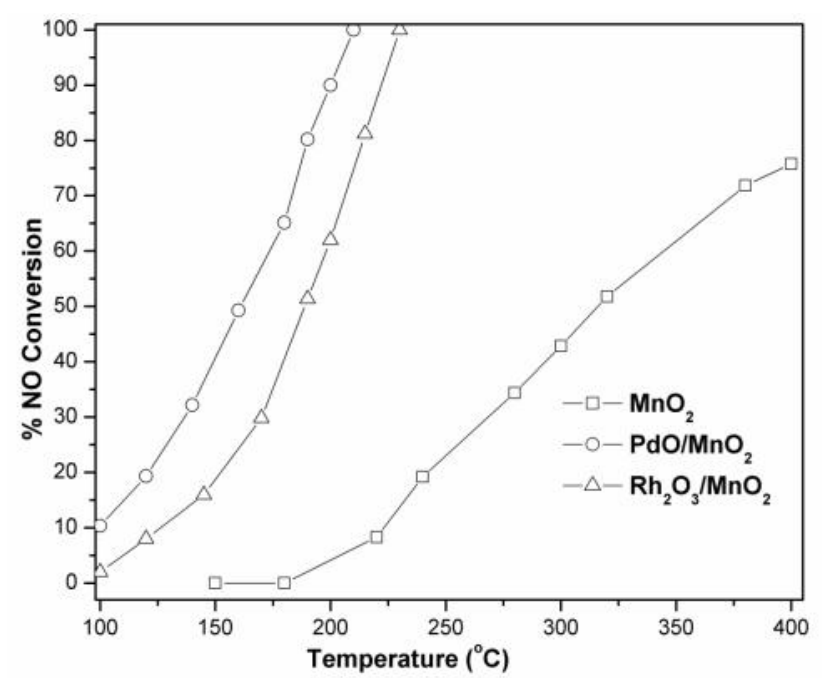

Figure 3. NO conversion in NO reduction with $\mathrm{CO}$ over all samples (5\% NO, $5 \% \mathrm{CO}$ in argon at $\left.5000 \mathrm{ml} \mathrm{h}^{-1}\right)$. 
${ }^{\circ} \mathrm{C}$ while that for $\mathrm{Rh}_{2} \mathrm{O}_{3} / \mathrm{MnO}_{2}$ is observed at $190{ }^{\circ} \mathrm{C}$. Thus, introduction of small amount of $\mathrm{PdO}$ and $\mathrm{Rh}_{2} \mathrm{O}_{3}$ over $\mathrm{MnO}_{2}$ greatly improves the catalytic activity of $\mathrm{NO}$ conversion and drastic decrease in temperature is observed for total conversion. It is a well-established fact that at low temperature surface is predominantly covered with $\mathrm{CO}$ and increase in temperature will favor reduction of active catalytic sites by desorption of $\mathrm{CO}_{2}$ with lattice oxygen participation. Reduced catalytic surface is prone for NO adsorption which will get reoxidised by dissociative desorption of NO. Pd and $\mathrm{Rh}$ are well known for $\mathrm{NO}$ reduction by $\mathrm{CO}$ over inert support like $\mathrm{Al}_{2} \mathrm{O}_{3}[17,18]$. Synergetic effect of these highly active metals on active support as $\mathrm{MnO}_{2}$ enhances their catalytic activity.

CO conversion occurs in-line with NO conversion. The higher activity is shown by $\mathrm{PdO} / \mathrm{MnO}_{2}$, indicating that the presence of $\mathrm{PdO}$ fastens the catalytic reaction of NO reduction by $\mathrm{CO}$. The activity for redox reactions were repeated three times with $\mathrm{PdO} / \mathrm{MnO}_{2}$ catalyst and the results were found to be satisfactory with no considerable decrease in the activity.

\subsection{Temperature Program Desorption of CO and NO}

CO desorption profiles are depicted in Figure 5. All catalysts show a typical single broad $\mathrm{CO}$ desorption peak. In $\mathrm{MnO}_{2}$, maxima for $\mathrm{CO}$ desorption at $173{ }^{\circ} \mathrm{C}$ is observed, which is comparatively at a lower temperature as compared to the $\mathrm{Rh}\left(210{ }^{\circ} \mathrm{C}\right)$ and $\mathrm{Pd}\left(254^{\circ} \mathrm{C}\right)$ supported catalysts. Quantum of $\mathrm{CO}$ chemisorbed over $\mathrm{PdO} / \mathrm{MnO}_{2}$ and $\mathrm{Rh}_{2} \mathrm{O}_{3} / \mathrm{MnO}_{2}$ is also found to be

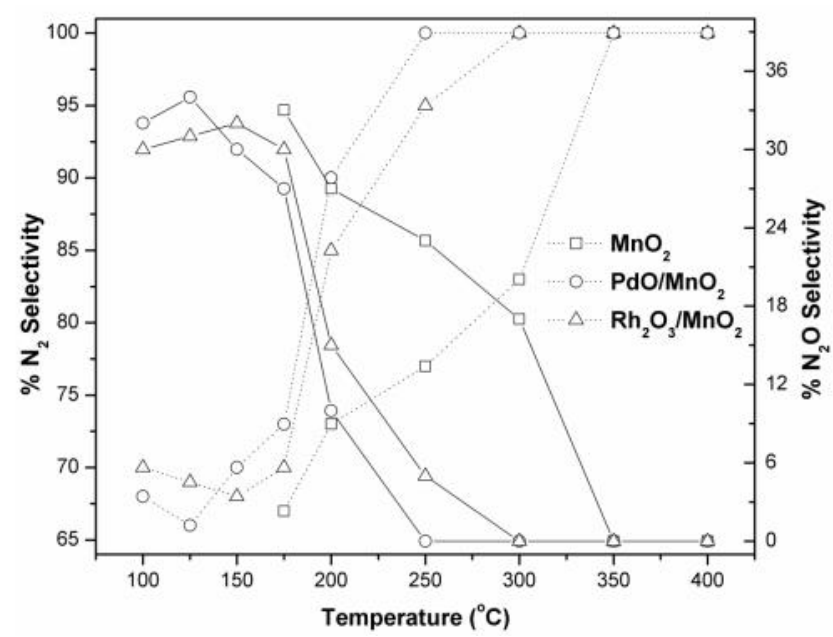

Figure 4. $\mathrm{N}_{2} \mathrm{O}$ (solid line) selectivity and $\mathrm{N}_{2}$ selectivity (dotted line) over all samples (5\% $\mathrm{CO}, 5 \% \mathrm{NO}$ in argon at $5000 \mathrm{ml} \mathrm{h}^{-1}$ ). higher than that of pristine $\mathrm{MnO}_{2}$ which indicates there is increase in number of active sites for $\mathrm{CO}$ adsorption that is needed for the reductive $\mathrm{CO}_{2}$ desorption from the oxide surface.

Desorption of NO over the catalyst is rather found complex in nature as observed from the Figure 6. $\mathrm{MnO}_{2}$ shows two distinct desorption peaks with peak maxima at 200 and $340{ }^{\circ} \mathrm{C}$ respectively. Former signifies a weak adsorption while the later suggests a strong adsorption. In case of supported catalysts, three distinct desorption maxima are observed. These peaks at higher temperature are due to stronger adsorption, indicative of more than one binding mode of NO with the catalyst. Since it is difficult to comment on the binding modes of NO solely based on TPD profile, FTIR spectrum of chemisorbed NO is recorded for all the catalysts along with the pristine $\mathrm{MnO}_{2}$ with and without $\mathrm{NO}$ adsorption. Pristine $\mathrm{MnO}_{2}$ show no prominent absorption in the region $1640-1250$ $\mathrm{cm}^{-1}$ as observed from the Figure 7. IR spectra shows characteristic $v(\mathrm{MN}-\mathrm{O})$ vibration in the range $1640-1250 \mathrm{~cm}^{-1}$ for the NO treated catalysts signifying NO adsorption [19]. For pristine $\mathrm{MnO}_{2}$, NO chemisorption shows only one major peak at $1627 \mathrm{~cm}^{-1}$, which is assigned to the terminal $v(\mathrm{MN}-\mathrm{O})$. Apart from this, intensities of other peaks in the range $1550-1250 \mathrm{~cm}^{-1}$ are found to be very weak, indicating only one major mode of adsorption. Bands at around $1630 \mathrm{~cm}^{-1}$ can be attributed to the M-NO- species [20]. IR data of the $\mathrm{Rh}$ supported catalysts shows peaks at 1381 and $1334 \mathrm{~cm}^{-1}$ [v(ONO)]. Whereas peaks at 1381 and $1265 \mathrm{~cm}^{-1}[v(\mathrm{ONO})]$

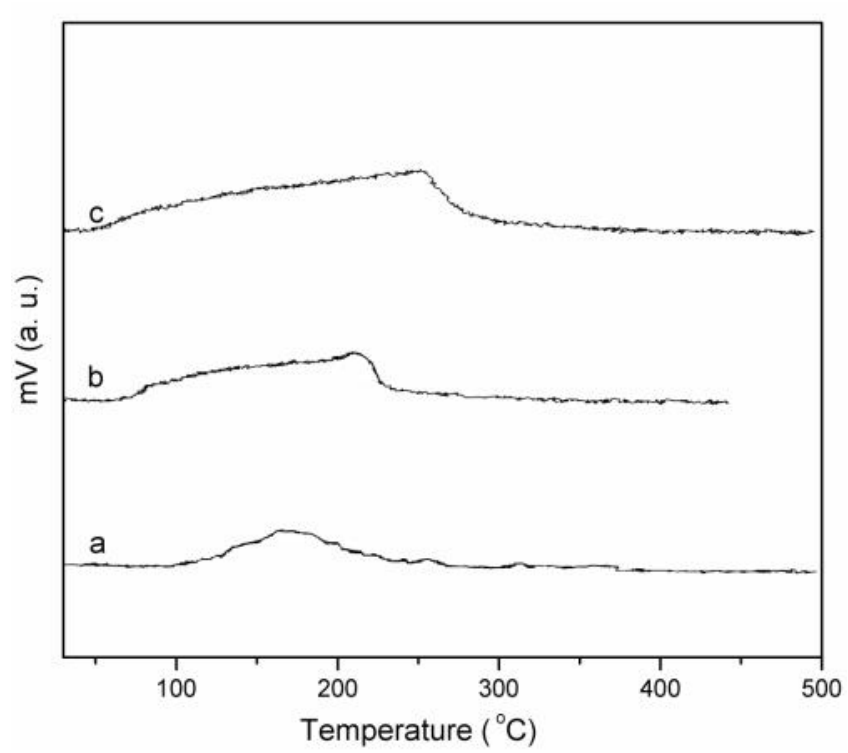

Figure 5. Temperature program desorption of $\mathrm{CO}$ over (a) $\mathrm{MnO}_{2}$, (b) $\mathrm{Rh}_{2} \mathrm{O}_{3} / \mathrm{MnO}_{2}$ and (c) $\mathrm{PdO} / \mathrm{MnO}_{2}$. 
are observed for Pd [21]. Rh and Pd are electron rich transition elements compared to $\mathrm{Mn}$. They are expected to lower the NO bond order by forming $\mathrm{M}-\mathrm{NO}^{-}$, that can in turn facilitate the dissociative desorption of NO, thus increasing the activity.

\section{Conclusion}

The supported catalysts $\mathrm{PdO} / \mathrm{MnO}_{2}$ and $\mathrm{Rh}_{2} \mathrm{O}_{3} / \mathrm{MnO}_{2}$ were prepared by wet impregnation method. The TEM and SEM images confirmed the nano-size formation of these catalysts along with elongated rod-like morphologies. Catalytic NO reduction by CO was performed on all the prepared catalysts. CO conversion was obtained in-line with NO conversion. The supported catalysts showed higher activity than pristine $\mathrm{MnO}_{2} \mathrm{PdO} / \mathrm{MnO}_{2}$ gave higher activity than $\mathrm{Rh}_{2} \mathrm{O}_{3} / \mathrm{MnO}_{2}$ for the catalytic reaction studied. Selectivity for $\mathrm{N}_{2}$ over $\mathrm{N}_{2} \mathrm{O}$ was also enhanced after dispersion of $\mathrm{Pd}$ and $\mathrm{Rh}$ on $\mathrm{MnO}_{2}$ in $\mathrm{NO}$ reduction reaction. Since the surface area of catalysts is uniform, enhancement in activity is attributed to an increase in active sites for the catalytic reaction. CO TPD confirmed an increased quantum of $\mathrm{CO}$ adsorption on supporting $\mathrm{Pd}$ and Rh. NO desorption profile over the supported catalysts showed multiple desorption peaks suggesting different modes of strong and weak adsorption. NO desorption studies were found to be in compliance with the FTIR, suggests multiple binding modes of $\mathrm{NO}$ and insights the formation of M-NO-species. In supported catalysts, forma-

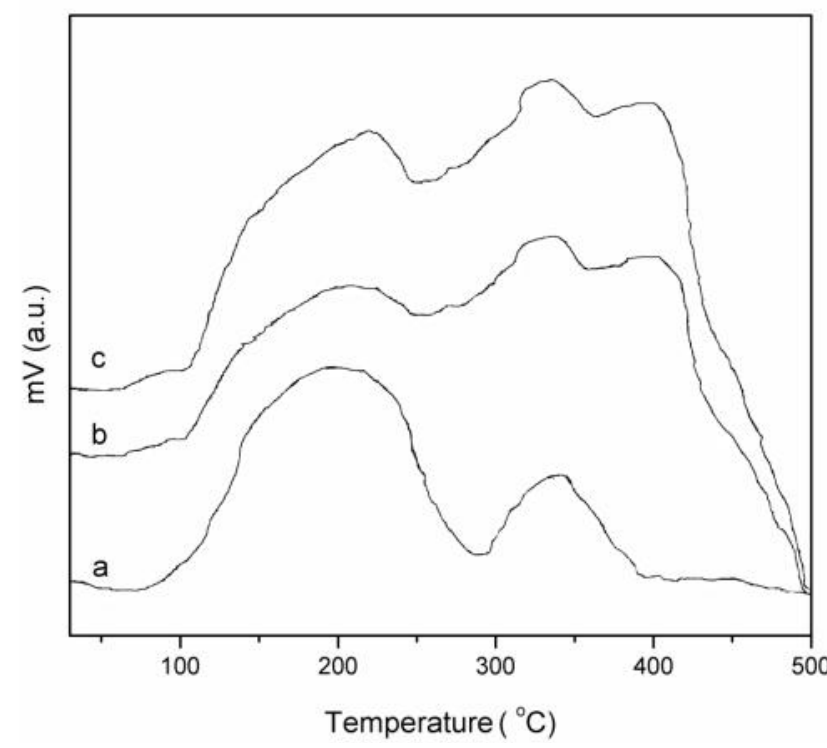

Figure 6. Temperature program desorption of $\mathrm{NO}$ over (a) $\mathrm{MnO}_{2}$, (b) $\mathrm{Rh}_{2} \mathrm{O}_{3} / \mathrm{MnO}_{2}$ and (c) $\mathrm{PdO} / \mathrm{MnO}_{2}$. tion of $\mathrm{M}-\mathrm{NO}^{-}$species considerably lowered bond order of $\mathrm{N}-\mathrm{O}$ which boosts the oxidative dissociative desorption of $\mathrm{N}_{2}$.

\section{Acknowledgements}

Authors are grateful to University Grant Commission, New Delhi, for the financial support.

\section{References}

[1] Thirupathi, B., Smirniotis, P.G. (2012). Nickel-doped $\mathrm{Mn} / \mathrm{TiO}_{2}$ as an efficient catalyst for the low-temperature SCR of $\mathrm{NO}$ with $\mathrm{NH}_{3}$ : catalytic evaluation and characterizations. Journal of Catalysis, 288: 74-83.

[2] Salker, A.V., Naik, S.J. (2009). Mechanistic study of acidic and basic sites for $\mathrm{CO}$ oxidation over nano based $\mathrm{Co}_{2-x} \mathrm{Fe}_{x} \mathrm{WO}_{6}$ catalysts. Applied Catalysis B: Environmental, 89: 246254.

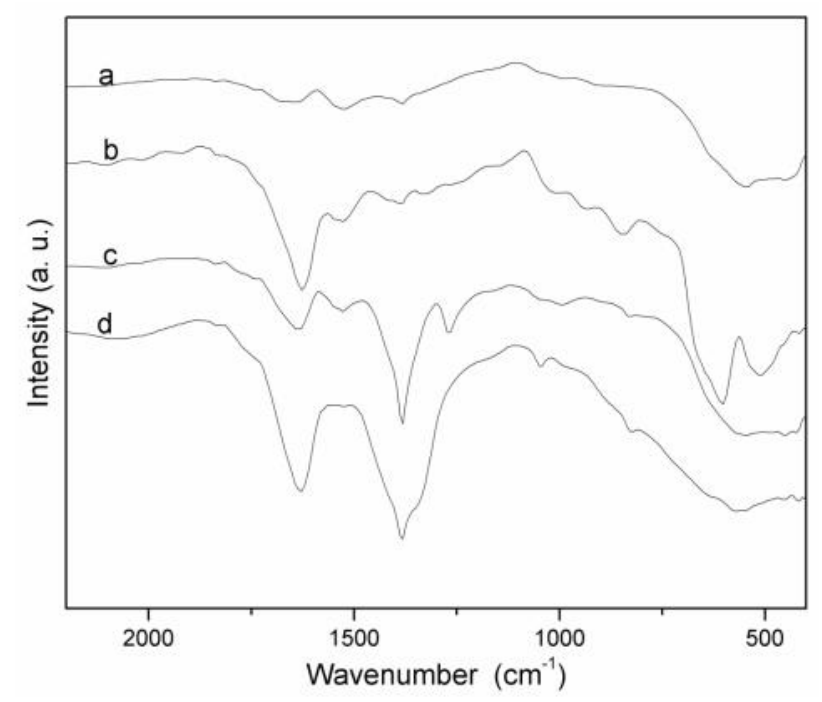

Figure 7. FTIR spectra of chemisorbed NO over (a) pristine $\mathrm{MnO}_{2}$ without $\mathrm{NO}$ adsorption and (b) $\mathrm{MnO}_{2}$ (c) $\mathrm{Rh}_{2} \mathrm{O}_{3} / \mathrm{MnO}_{2}$ and (d) $\mathrm{PdO} / \mathrm{MnO}_{2}$ on $\mathrm{NO}$ adsorption

\section{Supplementary figure}

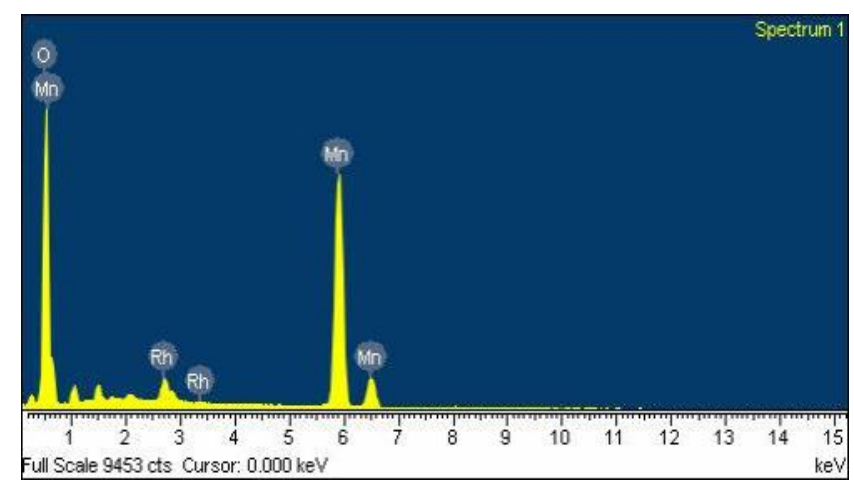


[3] Shan, J., Zhu, Y., Zhang, S., Zhu, T., Rouvimov, S., Tao, F. (2013). Catalytic Performance and In-situ Surface Chemistry of Pure a$\mathrm{MnO} 2 \mathrm{Nanorods}$ in Selective Reduction of NO and $\mathrm{N}_{2} \mathrm{O}$ with CO. Journal of Physical. Chemistry C, 117: 8329-8335.

[4] Granger, P., Parvulescu, V.I. (2011). Catalytic NOx Abatement Systems for Mobile Sources: From Three-Way to Lean Burn afterTreatment Technologies. Chemical Revision, 111: 3155-3207.

[5] Li, J., Chen, J., Ke, R., Luo, C., Hao, J. (2007). Effects of precursors on the surface Mn species and the activities for NO reduction over $\mathrm{MnO}_{\mathrm{x}} / \mathrm{TiO}_{2}$ catalysts. Catalysis Communication, 8: 1896-1900.

[6] Stankova, N.B., Khristova, M.S., Mehandjiev, D.R. (2001) Catalytic reduction of NO with $\mathrm{CO}$ on active carbon-supported copper, manganese, and copper-manganese oxides. Journal of Colloid Interface Science, 241: 439-447.

[7] Wan, H., Li, D., Dai, Y., Hu, Y., Liu, B., Dong, L. (2010). Catalytic behaviors of $\mathrm{CuO}$ supported on $\mathrm{Mn} 2 \mathrm{O} 3$ modified $\mathrm{Y}-\mathrm{Al} 2 \mathrm{O} 3$ for $\mathrm{NO}$ reduction by CO. Journal of Molecular $\mathrm{Ca}$ talysis A: Chemical, 332: 32-44.

[8] Patel, A., Shukla, P., Chen, J., Rufford, T.E., Rudolph, V., Zhu, Z. (2012). Activity of mesoporous $-\mathrm{MnO}_{\mathrm{x}}$ and $\mathrm{CuO} / \mathrm{m}-\mathrm{MnO}_{\mathrm{x}}$ for catalytic reduction of $\mathrm{NO}$ with $\mathrm{CO}$. Catalysis Today, 212: 38-44.

[9] Yu, Y., Zhao, J., Yan, Y., Han, X., He, H. (2013). Acyclic reaction pathway triggered by ammonia for the selective catalytic reduction of $\mathrm{NOx}$ by ethanol over $\mathrm{Ag} / \mathrm{Al}_{2} \mathrm{O}_{3}$. Applied $\mathrm{Ca}$ talysis B: Environmental, 136: 103-111.

[10] Lv, Y., Liu, L., Zhang, H., Yao, X., Gao, F., Yao, K., Dong, L., Chen, Y. (2013). Investigation of surface synergetic oxygen vacancy in $\mathrm{CuO}-\mathrm{CoO}$ binary metal oxides supported on $\mathrm{Y}-\mathrm{Al} 2 \mathrm{O} 3$ for NO removal by CO. Journal of Colloid Interface Science, 390: 158-169.

[11] Yao, X., Tang, C., Ji, Z., Dai, Y., Cao, Y., Gao, F., Dong, L., Chen, Y. (2013). Investigation of the physicochemical properties and catalytic activities of $\mathrm{Ce}_{0.67} \mathrm{M}_{0.33} \mathrm{O}_{2}\left(\mathrm{M}=\mathrm{Zr}^{4+}, \mathrm{Ti}^{4+}, \mathrm{Sn}^{4+}\right)$ solid solutions for NO removal by CO. Catalysis Science and Technology, 3: 688-698.

[12] Xue, X. Y., Xing, L. L., Wang Y.G., Wang, T.H. (2009). Preparation, characterization and electrical transport properties of individual $\mathrm{a}-\mathrm{MnO}_{2}$ and $\mathrm{B}-\mathrm{MnO}_{2}$ nanorods. Solid State Science, 11: 2106-2100.
[13] Kunkalekar, R. K., Salker, A.V. (2013). Activity of $\mathrm{Pd}$ doped and supported $\mathrm{Mn}_{2} \mathrm{O}_{3}$ nanomaterials for CO oxidation. Reaction Kinetics Mechnism and Catalysis, 108: 173-182.

[14] Kunkalekar, R. K., Salker, A.V. (2010). Low temperature carbon monoxide oxidation over nanosized silver doped manganese dioxide catalysts. Catalysis Communication, 12: 193196.

[15] Njagia, E. C., Chen C. H., Genuino, H., Galindo, H., Huang, H., Suib, S. L. (2010). Total oxidation of $\mathrm{CO}$ at ambient temperature using copper manganese oxide catalysts prepared by a redox method. Applied Catalysis B: Environmental, 99: 103-110.

[16] Salker, A.V., Kunkalekar, R. K., (2009). Palladium doped manganese dioxide catalysts for low temperature carbon monoxide oxidation. Catalysis Communication, 10: 1776-1780.

[17] Lee Y. W., Gulari, E. (2004). Improved performance of $\mathrm{NOx}$ reduction by $\mathrm{H}_{2}$ and $\mathrm{CO}$ over a $\mathrm{Pd} / \mathrm{Al} 2 \mathrm{O} 3$ catalyst at low temperatures under lean-burn conditions. Catalysis Communication, 5: 499-503

[18] Li, M., Wu, X., Cao, Y., Liu, S., Weng, D., Ran, R. (2013). NO reduction by CO over $\mathrm{Rh} / \mathrm{Al}_{2} \mathrm{O}_{3}$ and $\mathrm{Rh} / \mathrm{AlPO}_{4}$ catalysts: Metalsupport interaction and thermal aging. Journal of Colloid Interface Science, 408: 157-163

[19] Nakamoto, K. (2009). Infrared and Raman spectra of inorganic and coordination compounds, Part A, 6th edition. Wiley, United State.

[20] Long R.Q., Yang R.T. (1999). In Situ FT-IR Study of Rh-Al-MCM-41 Catalyst for the Selective Catalytic Reduction of Nitric Oxide with Propylene in the Presence of Excess Oxygen, Journal Physical Chemistry B, 103: 2232-2238.

[21] Worz A. S., Judai K., Abbet S., Heiz U.J. (2003). Cluster Size-Dependent Mechanisms of the $\mathrm{CO}+\mathrm{NO}$ Reaction on Small $\mathrm{Pd}_{\mathrm{n}}(\mathrm{n} \leq$ 30) Clusters on Oxide Surfaces, Journal of American Chemical Society, 125: 7964-7970. 